\title{
A new locality record for the narrowly endemic alpine ginger (Roscoea tumjensis Cowley) of the Nepalese Himalayas
}

\author{
Babu Ram Paudel \\ Department of Botany, Prithvi Narayan Campus, Tribhuvan University, Pokhara, Nepal \\ E-mail:brp2033@gmail.com
}

[Received 20.10.2020; Revised 19.12.2020; Accepted 20.12.2020; Published 31.12.2010]

\begin{abstract}
Roscoea tumjensis Cowley (Zingiberaceae) is a narrowly endemic Nepalese alpine ginger that was previously known to occur only with a single population at Tumje in Central Nepat, the type locality. My extensive observations over eight years (2012 - 2019) across the several mountains in Nepal encompassing 30 potential populations indicated that R. tumjensis occurs at Tistung-DamanSimbhangjyang region only. This finding reveals the narrow and disjunct distribution of $\mathrm{R}$. tumjensis in the Nepalese Himalayas.
\end{abstract}

Key words: Alpine ginger, Roscoea tumjensis, distribution, Nepal Himalaya, Endemism

Zingiberaceae is basically a tropical family but the genus Roscoea is distributed in temperate to alpine regions and mostly in the Himalayas. The genus includes 22 species that are distributed between $1200 \mathrm{~m}$ and $4880 \mathrm{~m}$ a.m.s.l. from Kashmir in the west through the Himalayas in Nepal, India, Bhutan, and south-west China (Cowley 1982, 2007). In regard to its distribution, the genus forms two disjunct clades, Himalayan and North-Indo-Chinese, that are separated by a topographic barrier of the Brahmaputra River (Ngamriabsakul et al. 2000; Cowley 2007; Zhao et al. 2016). Out of its 22 known species, eight are belonging to the Himalayan clade (Cowley 2007).

Nepal is the centre of origin and diversification of the Himalayan species of Roscoea (Zhao et al. 2016). All the eight Himalayan Roscoea spp. are known to exist in Nepal with four species endemic to the country (Cowley 2007). Roscoea tumjensis Cowley, a member of the Himalayan clade, is very narrowly distributed in central Nepal and is characterized by the presence of pale lilac, lilac-blue, or bright purple flowers. Flowering in this species occurs precociously before the leaves are fully emerged (Figure 1) (Cowley \& Wilford 1998; Cowley 2007; Paudel et al. 2019). It was known to exist only at a site, Shiar Khola, Tumje, west of Kathmandu (Type locality). The plant grows on grassy areas on rocky hillsides on the edge of mixed woodlands, between $2740-3050 \mathrm{~m}$. Although McCosh's collection from Junbesi in May 1964 at $3050 \mathrm{~m}$ was formerly treated as R. tumjensis (Hara et al. 1978; Cowley 1982), later it was confirmed that the species occurring at Junbesi is actually R. auriculata (Cowley \& Wilford 1998). Thus, till date, R. tumjensis has not been recorded beyond its type locality.

My field studies during 2011 to 2019 on the distribution, ecology, and evolution of Himalayan Roscoea spp. in the Nepalese Himalayas revealed a new population of R. tumjensis at a site (Tistung-Daman-Simbhangiyang) beyond the type locality (Figure 2) and was previously misidentified as R. purpurea. Upon the close examination of flowering phenology and the floral traits, the species of this population is now identified as R. tumjensis. The identification was further validated by consulting with the relevant literature (Cowley \& Wilford 1998; Cowley 2007) and studying the specimens of R. tumjensis at KATH herbarium, Nepal. In this new locality, the species was found growing abundantly either in the open meadow or under the 

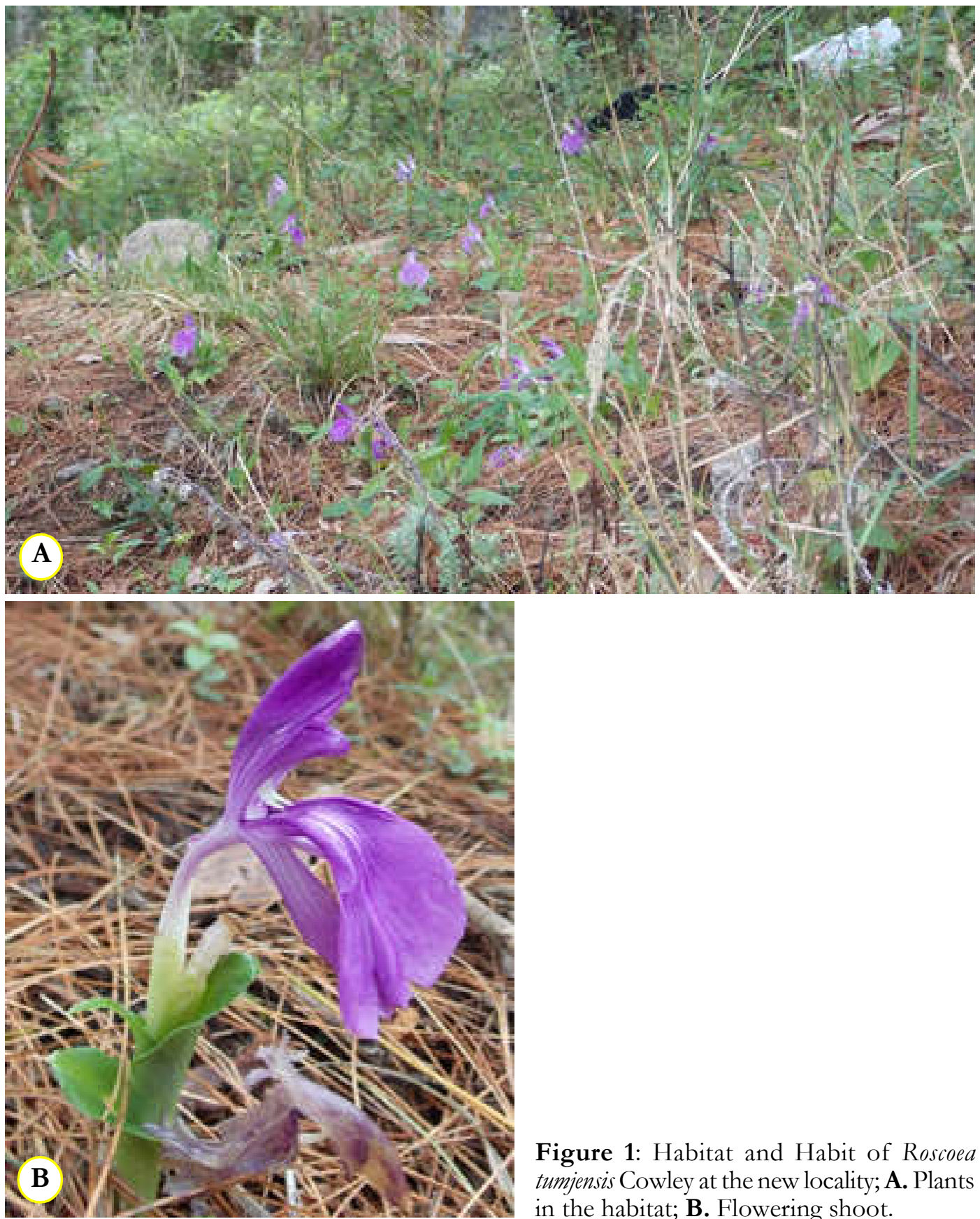

Figure 1: Habitat and Habit of Roscoea tumjensis Cowley at the new locality; A. Plants in the habitat; B. Flowering shoot.

canopy of Pinus, Rhododendron, and Oak. However, the density was higher in open meadow than under the canopy.

Roscoea tumjensis Cowley, Kew Bull. 36 (4): 755 - 756. 1982.

Type: Protologue: R. tumjensis Cowley: R. bumeanae affinis sed labello quam petalum dorsale unguiculatum multo majore, bracteis acutis non obtusis, staminodiis circularibus vel ellipticis non asymmetrice obovatis, appendicibus antherarum obtusis non acutis, foliorum apicibus 


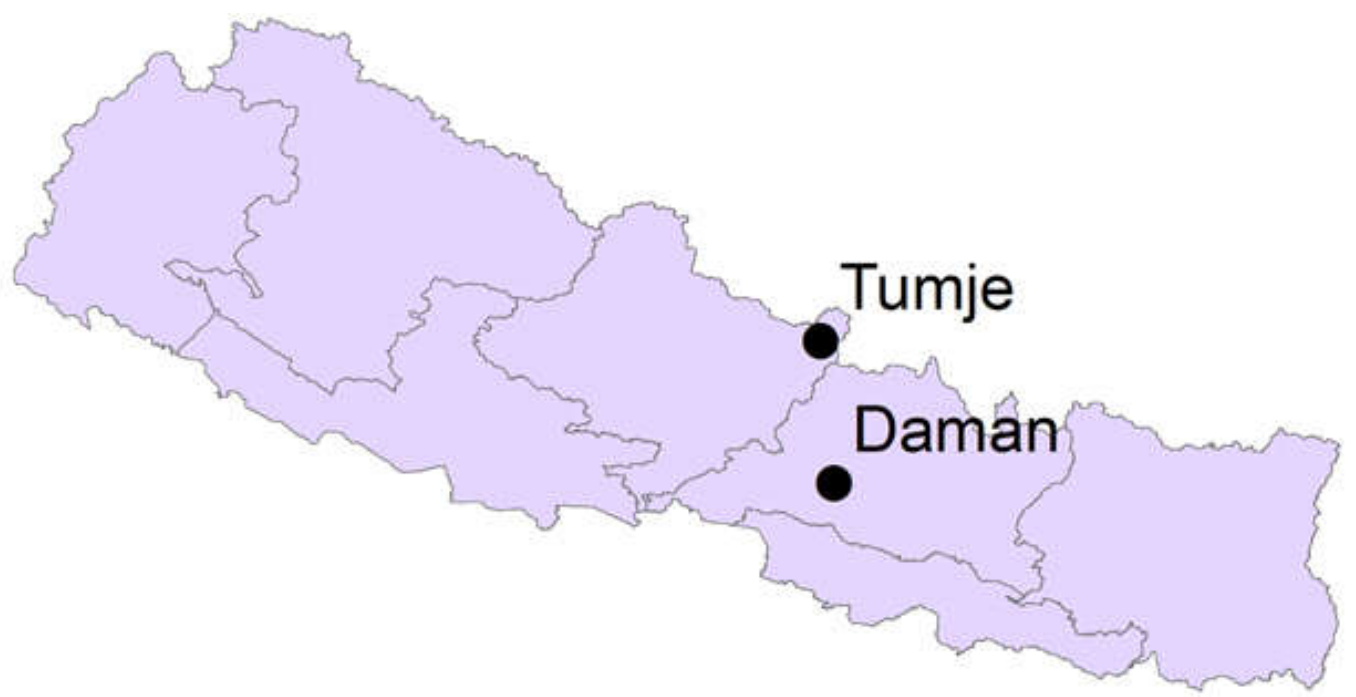

Figure 2. Distribution of Roscoea tumjensis Cowley in the Nepalese Himalayas. Tumje refers to the type locality while Daman refers to the new locality record

obtusis non acutis basibus conspicue auriculatis differ. Typus: Nepal, Shiar Khola River, above Tumje,2740 m,15 June 1953, Gardner 790 (Holotype: BM, Isotype: E); Junbesi, 3050 m, May 1964, McCosh 65 (BM).

[R. chamaeleon sensu Hara in Hara et al., Enum. Fl. Pl. Nepal. 1: 61 (1978), as to Gardner 525 and McCosh 65].

[R. purpurea var. auriculata sensu Hara in Hara et al., Enum. Fl. Pl. Nepal.1: 61 (1978), in part, as to Gardner 525].

Habitat: Grassy area on rocky hillside, 2740 - $3050 \mathrm{~m}$.

Phenology: Flowering from May to June/July.

Distribution: Central Nepal (Gorkha District- Shiar Khola, above Tumje, and Makawanpur District- Tistung-Daman- Simbhangjyang).

Specimen examined: Central Nepal, Bagmati Province, Makawanpur District, Tistung-DamanSimbhangjyang, 2014 - 2530 m, June 10, 2019, BR. Paudel (KATH).

The findings of $R$. tumjensis at Tistung-Daman- Simbhangjyang, away from its type locality suggests its disjunct distribution across the Nepal-Himalayas. The current finding revealed the relatively wider $(2014-2530 \mathrm{~m})$ altitudinal distribution of the species with a considerably much lower distribution than in the type locality. So far, around 30 potential populations have been surveyd, but out of those only one additional population of $R$. tumjensis in the Nepalese Himalayas is now confirmed. Consistent with the type locality, in the new locality also $R$. tumjensis preferably grows on open meadow on rocky hillsides at the edge of mixed woodlands. Zhao et al. (2017) suggests that R. tumjensis is a putative hybrid species, however, the potential evolutionary trajectory remains unclear. It is likely that the difference in the pollination system might have played a key role for the speciation and diversification of the Himalayan Roscoea spp. (Paudel et al. 2015, 2017, 2019). A previous finding suggests that $R$. tumjensis exhibit a complete reproductive isolation with one of the widespread Himalayan Roscoea, which may have played a key role for the disjunct distribution of R. tumjensis (Paudel et al. 2018). However, much further study is needed to explore why $R$. tumjensis have very narrow and disjunct 
distribution in the Nepalese Himalayas. Considering its rarity of distribution, and observed potential threats, mainly due to deforestation, forest fire, overgrazing and road expansion, especially in the new locality, this endemic Nepalese ginger needs immediate attention for its conservation.

\section{Acknowledgements}

The author is thankful to Mr. Binod Ghimire for assistance in the field; the Department of Plant Resources and local government bodies of Nepal for providing research permission, and KATH herbarium Kathmandu for allowing in studying the specimens of R. tumjensis. This study was supported by the postdoctoral funds of the Chinese government (W8163003, W8163007, and WX069051).

\section{LITERATURE CITED}

Cowley, E. J. 1982. A revision of Roscoea (Zingiberaceae ). Kew Bull. 36: 747 - 777.

Cowley, E. J. 2007. The Genus Roscoea. Royal Botanic Garden, Kew, UK.

Cowley, E. J. \& Wilford, R. 1998. Roscoea tumjensis. Curtis's Botanical Magazine 15: 220 - 225, pl 349.

Hara, H.; Stearn, W.T. \& Williams, L.H.J. 1978. An Enumeration of the Flowering Plants of Nepal. Vol. 1. British Museum (Natural History), London. Pp. 61.

Ngamriabsakul, C.; Newman, M.F. \& Cronk, Q.C.B. 2000. Phylogeny and disjunction in Roscoea (Zingiberaceae). Edinb. J. Bot. 57: 39 - 61.

Paudel, B. R.; Burd, M.; Shrestha, M.; Dyer, A. G. \& Li, Q.-J. 2018. Reproductive isolation in alpine gingers: How do coexisting Roscoea (R. purpurea and R. tumjensis) conserve species integrity? Evolution 72: 1840 - 1850.

Paudel, B. R.; Kessler, A.; Shrestha, M.; Zhao, J. L. \& Li, Q.-J. 2019. Geographic isolation, pollination syndromes, and pollinator generalization in Himalayan Roscoea spp. (Zingiberaceae). Ecosphere 10:e2943.

Paudel, B. R.; Shrestha, M.; Dyer, A. G. \& Li, Q.-J. 2017. Ginger and the beetle: Evidence of primitive pollination system in a Himalayan endemic alpine ginger (Roscoea alpina, Zingiberaceae). Plos One 12:e0180460.

Paudel, B.R.; Shrestha, M.; Dyer, A.G.; Zhu, X.; Abdusalam, A. \& Li, Q.-J. 2015. Out of Africa/ : evidence of the obligate mutualism between long corolla tubed plant and long tongued fly in the Himalayas. Ecol. Evol. 5: 5240 - 5251.

Zhao, J. L., Xia, Y. M.; Cannon, C. H.; Kress, W. J. \& Li, Q.- J. 2016. Evolutionary diversification of alpine ginger reflects the early uplift of the Himalayan-Tibetan Plateau and rapid extrusion of Indochina. Gondwana Research 32: 232 - 241.

Zhao, J. L.; Zhong, J.; Fan, Y. L.; Xia, Y. M. \& Li, Q.- J. 2017. A preliminary species-level phylogeny of the alpine ginger Roscoea: Implications for speciation. J. Syst. Evol. 55: 215 224. 